\title{
EVOLVING TRENDS OF SUPPLIER SELECTION CRITERIA AND METHODS
}

\section{S. Thiruchelvam and J.E. Tookey}

\author{
School of Engineering \\ Auckland University of Technology \\ Private Bag 92006, Auckland 1020, New Zealand \\ Tel-+64 99219999 ext (6635), Fax-+64 99219973 \\ Email: sthiruch@aut.ac.nz
}

\begin{abstract}
The increasing importance of supply chain management (SCM) is forcing organisations to reconsider and improvise their purchasing-related matters. In lieu of that, the supplier selection process plays an important role in purchasing activity. The supplier selection process has undergone significant changes in the past forty years. These changes have been beneficial to both the purchasing clients and the suppliers. The supplier selection decision making process involves multiple criteria comprising both qualitative and quantitative aspects. Sometimes, there might be some contradictions between tangible and intangible criteria which may necessitate a trade-off between conflicting criteria. This paper provides an overall picture of research on supplier selection problems and supplier selection practices. Different selection criteria, emerging issues of supplier selection and the solutions for these problems are summarised. This review shows that the application of a structured decision making technique is important, especially under the complex conditions that include both qualitative and quantitative criteria.
\end{abstract}

Keywords: Supplier selection; decision making; criteria; method.

\section{INTRODUCTION}

Supplier selection is one of the most crucial components of the purchasing function of a firm (Florez-Lopez, 2007). It becomes a strategic decision when the purchasing organisation attempts to establish a long-term and win-win business relationship with its suppliers. Companies have become gradually more dependent on suppliers to supply goods and to deliver services which were formerly provided in-house in order to specialise and concentrate on their core competencies. In the SCM concept, a strategic, long-term cooperation in partnership between the buyer and the supplier should be reached to avoid wastage of resources within the logistics chain (Lasch and Janker, 2005). Echoing such a need, a prerequisite for nourishing a strong buyer-supplier relationship is to have a small number of suppliers (Sarkar and Mohapatra, 2006). Therefore, an identification of decision making criteria together with the right supplier selection methods are the driving factors determining a firm's growth and competitiveness.

In a survey conducted by Ying (2000), the supplier selection process is the main area requiring improvement to facilitate a better outsourcing process. Developing a proper supplier evaluation system has become a must in building an effective SCM. The success of outsourcing activity is highly dependent on the successful selection of suppliers. Therefore, the selection of the right decision making criteria paralleled with 
the right decision making technique is crucial for identifying the right supplier. Both elements ensure that decision maker's personal perceptions and objectives are supported in the pursuit of achieving the organisation's procurement objectives. A well-structured and systematic decision making technique is critical for the corporate and business strategy of the purchasing organisation to be aligned and achieved.

Since suppliers are one of the most essential components of the supply chain, effective supplier selection and evaluation is considered to be one of the important responsibilities of purchasing managers. The supplier evaluation process is purely meant to minimise purchase risk and maximise the overall value to the purchaser (Monczka et al., 1998). However, supplier selection is considered a key strategic decision in outsourcing, which is prone to errors (Wadhwa and Ravindran, 2007). In order to select the right supplier, comprehensive and configurable metrics for supplier selection must be outlined early in the process. The supplier evaluation involves rating a supplier's value by measuring the selected supplier's capability and performance. For supplier selection, decision makers have defined a set of criteria to determine the performance of prospective suppliers both in the previous and current contracts. This enables decision makers to rank the order of their preferred suppliers. In reality, it is always a difficult task for purchasing managers to select the right supplier. This is due to the stringent and careful assessment of bidders' strengths and pitfalls which must be performed prior to the award of the contract. The supplier selection process would be an easier task if only one criterion were to be considered in the decision making process. However, in real practice, a wide range of criteria is carefully assessed by purchasing managers to select the best supplier. Supplier selection is the outcome of a complex decision considering qualitative and quantitative criteria. There are numerous decision making criteria that should be considered in supplier selection, bearing in mind that each criterion influences the decision making process with an equal or different weighing factor.

The main purpose of this paper is to address the supplier selection criteria being considered by various industries. This preliminary literature review is part of a research initiative on the improvement of supplier selection for the Malaysian electricity supply industry. Supplier selection for electricity generating, transmitting and distributing infrastructures is an important factor for the Malaysian electricity supply industry. This is since building infrastructure is a long-term investment for any power generating company, and the success of its services is directly affected by the supplier selection decision.

\section{TYPES OF PURCHASING SITUATIONS}

The main aim of this classification is to categorise the decision making process in different industrial buying situations. Portfolio models have been used to understand and to assist with managing different kinds of supplier relationships (Olsen and Ellram, 1997). The portfolio model concept was originally developed by Markowitz (Markowitz, 1952; Dubois and Pedersen, 2001), who used it as an instrument for managing equity investments. His point of departure was that rational investors will (or should) select portfolios which maximise the individual investor's utilities by maximising the expected return for a given level of risk or minimising the risk for a given level of expected return. Faris et al. (1967) distinguished three typical situations of varying complexity as shown in Table 1 . The distinct difference between these three 
categories is the level of uncertainty regarding the purchase and the familiarity of prospective suppliers to the purchasing organisation.

Table 1. Classification of purchasing situations (Faris et al., 1967)

\begin{tabular}{llll}
\hline $\begin{array}{c}\text { Type of buying } \\
\text { situation }\end{array}$ & $\begin{array}{c}\text { Product/Service } \\
\text { category }\end{array}$ & Nature of decision making & \multicolumn{1}{c}{$\begin{array}{c}\text { Supplier(s) } \\
\text { category }\end{array}$} \\
\hline $\begin{array}{l}\text { New task } \\
\text { situation }\end{array}$ & New items & $\begin{array}{l}\text { No past experience, more } \\
\text { information required for } \\
\text { selection }\end{array}$ & $\begin{array}{l}\text { Not known to } \\
\text { decision makers }\end{array}$ \\
Modified rebuy & $\begin{array}{l}\text { New and } \\
\text { modified items }\end{array}$ & $\begin{array}{l}\text { Considering past experience } \\
\text { with the necessity of additional } \\
\text { information }\end{array}$ & $\begin{array}{l}\text { Known with } \\
\text { inclusion of new } \\
\text { ones }\end{array}$ \\
Straight rebuy & Recurring items & $\begin{array}{l}\text { Past experience is considered } \\
\text { sufficient for selection }\end{array}$ & $\begin{array}{l}\text { Existing } \\
\text { supplier(s) }\end{array}$ \\
\hline
\end{tabular}

In a later development which became the most famous model, Kraljic's portfolio approach took into account of complexity of the supply market and levels indicating the importance of purchasing (Caniels and Gelderman, 2005). These two variables influence decision makers in determining the type of supply strategy the purchasing company needs in determining the supply strategy of the purchasing company. Kraljic (1983) classified purchasing into strategic, bottleneck, leverage and routine purchases, as summarised in Table 2. The purchasing company shall classify all its purchased products in terms of profit impact and supply risk. This will allow the company to weigh the suppliers' bargaining power against its own power. Strategic items are products having high value to the organisation in terms of a large impact on profit and a high supply risk. Examples are cables, capacitors, electric meters, poles (steel, concrete and wood), transformers and transmission towers. Bottleneck items such as breakers, condensers, bearings, seals, boilers (parts and services), turbine (parts and services) and substation equipment and parts have a moderate impact on the financial outcome of a firm; however, the firm is vulnerable with regard to their supply. Leverage products can be obtained from various suppliers and routine items usually have small value per unit. Typical leverage products are advertising, corporate travel, printing, freight and environmental services. Examples of routine products are clothing, food services, office supplies, furniture and vehicle (fuel, lubricants and parts).

De Boer et al. (2001) incorporated both classifications into a modified framework to offer the purchaser a manageable number of typical, different supplier selection situations with associated ways of carrying out and organising the supplier selection process, as shown in Table 3. In new task situations, final decisions depend on the offerings made by the bidders as there has not been any prior business relationship between the purchasing company and the bidder. For the purchase of leverage items, there are many suppliers to be considered for the contract award. De Boer agrees that since there are many suppliers available for routine items, limitation to a maximum of two suppliers should be imposed in order to achieve a highly efficient ordering and administration procedure. High value and the savings potential of these items rationalise the frequency of supplier selection. However, for strategic and bottleneck items, there are limited choices of suppliers and it is much preferred to continuously evaluate the existing supplier. This is attributable the unique specification and scarcity of the 
required items. To ensure continuous business operation, firms usually have a large number of products or services accompanied by a variety of suppliers, which requires different treatment. Therefore, it is essential to have a deep understanding of the purchasing situation for the sustainable purchasing management practice.

Table 2. Purchasing portfolio model (Kraljic, 1983)

\begin{tabular}{cll}
\hline & \multicolumn{1}{c}{ Low supply risk } & \multicolumn{1}{c}{ High supply risk } \\
\hline & Leverage items & Strategic items \\
- Many local suppliers & - Established global suppliers \\
High profit & - Mix of commodities and specified & - Scarce and high value materials \\
impact & materials & • Long term contract \\
& - Short to medium term contract & - Centralised decision making \\
& - Mainly decentralised decision & \\
& making & Bottleneck items \\
& Routine items & - New suppliers with new technology \\
Low profit & - Established local suppliers & - Mainly specified materials \\
impact & materials & - Medium term contracts \\
& - Short-term contracts & - Decentralised but centrally \\
& • Decentralised decision making & coordinated decision making \\
\hline
\end{tabular}

Table 3. Supplier selection framework (De Boer et al., 2001)

\begin{tabular}{|c|c|c|c|}
\hline New task & $\begin{array}{l}\text { Modified rebuy } \\
\text { (leverage items) }\end{array}$ & $\begin{array}{l}\text { Straight rebuy } \\
\text { (routine items) }\end{array}$ & $\begin{array}{c}\text { Straight rebuy } \\
\text { (strategic/bottleneck) }\end{array}$ \\
\hline $\begin{array}{l}\text { - Use a supplier or } \\
\text { not? } \\
\text { - One-off decision }\end{array}$ & $\begin{array}{l}\text {-Use more, fewer } \\
\text { or other suppliers } \\
\text { - Repeating } \\
\text { decision }\end{array}$ & $\begin{array}{l}\text { - Replacing the } \\
\text { current supplier? } \\
\text { - Repeating } \\
\text { decision }\end{array}$ & $\begin{array}{l}\text { - How to deal with } \\
\text { the supplier? } \\
\text { - Repeating } \\
\text { evaluation }\end{array}$ \\
\hline $\begin{array}{l}\text { - No historical data } \\
\text { on suppliers } \\
\text { available }\end{array}$ & $\begin{array}{l}\text {-Historical data on } \\
\text { suppliers } \\
\text { available }\end{array}$ & $\begin{array}{l}\text { - Historical data } \\
\text { on suppliers } \\
\text { available }\end{array}$ & $\begin{array}{l}\text { - Historical data on } \\
\text { suppliers available }\end{array}$ \\
\hline $\begin{array}{l}\text { - Small initial set of } \\
\text { suppliers }\end{array}$ & $\begin{array}{l}\text { •Large set of } \\
\text { initial suppliers }\end{array}$ & $\begin{array}{l}\text { - Large set of } \\
\text { initial suppliers }\end{array}$ & $\begin{array}{l}\text { - Very small set of } \\
\text { suppliers }\end{array}$ \\
\hline $\begin{array}{l}\text { - Ranking rather } \\
\text { than sorting }\end{array}$ & $\begin{array}{l}\text {-Ranking rather } \\
\text { than sorting }\end{array}$ & $\begin{array}{l}\text { - Ranking rather } \\
\text { than sorting }\end{array}$ & $\begin{array}{l}\text { - Evaluation rather } \\
\text { selection }\end{array}$ \\
\hline
\end{tabular}

\section{SUPPLIER SELECTION PROBLEM}

Although, historically, supplier selection was supposedly a straightforward matter, the process was shadowed by some difficulties such as (1) a growing number of potential suppliers; (2) a growing number of attributes; (3) an increasing number of situational contexts that affect the appropriateness of specific supplier attributes; and (4) difficulty in identifying and defining supplier selection parameters (Altinoz et al., 2010). A large number of suppliers in the market has a positive impact on the purchasing client as dependency towards a particular supplier has been reduced. However, the drawback of this situation is the greater likelihood of not selecting the best supplier. Dickson (1966) 
in his seminal work found 23 important attributes used for the evaluation and selection of suppliers. Embarking from Dickson's work, many articles have been published in subsequent years considering other factors (Lambert et al., 1997, Weber et al., 1991, Dickson, 1966). Due to the many factors to be considered, purchasing managers might choose an easier path of evaluation based on certain important criteria and ignoring the rest. A larger number of attributes also contributes to the complication of being assigned consistent and meaningful weights. The selection decision also becomes more difficult as the number of business rules that must be considered increases. At times, different suppliers are selected although the characteristics and ratings of the suppliers have not changed. This happens due to changes in the current marketing policy and the company's strategic goals or manufacturing limitations which might override the choice of keeping the previous supplier. Difficult situations are encountered when it comes to the quantification of certain criteria such as flexibility, responsiveness and attitude. This is opposite to the ease of measuring pricing and delivery performance of a particular supplier. Sometimes, decision-makers are also forced to decide using incomplete data. Another common problem is the issue of how many suppliers can be used for each purchased item (Wisner et al., 2005). In single sourcing, suppliers are considered to be capable of satisfying the buyer's requirement (Xia and Wu, 2007). The purchaser only needs to make one decision as to which supplier is the best. However, in multiple sourcing, purchasers need to decide which are the best suppliers and how big an order should be placed with each selected supplier. Table 4 shows the summary made by Wisner et al. (2005) on the reasons favouring single and multiple sourcing.

Table 4. Reasons favouring the use of single versus multiple sourcing (Wisner et al., 2005)

\begin{tabular}{ll}
\hline \multicolumn{1}{c}{ Single Sourcing } & \multicolumn{1}{c}{ Multiple Sourcing } \\
\hline - Easier to establish strategic alliance & - Demand exceeds the capacity of a single \\
relationship & supplier \\
- Less quality variability from other suppliers & - Spread the risk of supply interruption \\
- Ability to lower the purchase cost per unit & - Encourages competition among \\
- Transportation economies since volume is & suppliers in terms of price and quality \\
involved & - More information on market conditions, \\
- Proprietary product or process purchase & new product and technologies \\
- Volume too small to split & $\begin{array}{l}\text { Boosts small, local, women or minority } \\
\text { owned business }\end{array}$ \\
\hline
\end{tabular}

\section{REVIEW OF SUPPLIER SELECTION CRITERIA}

The identification and analysis of criteria for the selection and evaluation of suppliers has been the central focus of many academics and practitioners. Research on supplier selection criteria began in early 1960s when it was known as vendor selection. Supplier criteria are divided into quantitative and qualitative attributes. The selection of suitable criteria also depends on the purchasing situation, as discussed earlier. The basic criteria such as cost, quality and delivery performance are still widely used. However, the range of criteria considered has evolved into a wider matrix parallel with the development of SCM philosophy. Sarkar and Mohapatra (2006) defined performance and capability as the two key dimensions of a supplier's abilities. Performance is defined as the demonstrated ability of a supplier to meet a purchaser's short-term requirements in 
terms of cost, quality, service and other short-term criteria. Capability is defined as the supplier's potential that can be leveraged to the buyer's advantages in the long term. Most performance factors are quantitative and can be measured relatively easily while most capability factors are qualitative and present measurement problems. These criteria can be broken down into different categories related to the supplier's overall performance. Some of the main categories, as reported by Ellram (1990) include financial, organisational culture and strategy and technology issues.

In his study, Dickson (1966) validated 23 criteria for assessing a supplier's performance as listed in Table 5 (indicated by $*$ ). He conducted a questionnaire survey mailed to about 300 organisations. Respondents were asked to assess the importance of each criterion on a five point scale; of extreme, considerable, average, slight and no importance. In his study, it was observed that price was not the most important factor in supplier selection. The ability of each supplier to meet the required quality was an extremely important criterion and reciprocal arrangements had slight importance on the supplier evaluation. Thereafter, quite a number of researchers continued studying the effects of various criteria in the supplier selection process. In the early days, price was the sole factor determining the suitable supplier. However, the selection attributes have been expanded and some new ones have been introduced responding to the growth of new business needs.

Weber et al. (1991) re-examined Dickson's work by reviewing published articles between 1966 and 1990. They reported that 47 of the 74 reviewed articles used multiple criteria as listed by Dickson for the selection process. They stressed that important JustIn-Time (JIT) components such as quality, delivery, net price, geographical location, production facilities and capacity have been given utmost priority by many purchasing firms. In a later work, Cheraghi et al. (2004) continued to extend the initial work of these key players to obtain the current perspective on supplier selection by analysing articles published between 1990 and 2001. It was found that reliability, flexibility, consistency and the long-term relationship were significant new entrants onto the list of critical success factors for supplier selection. They concluded that several criteria, such as operating controls, packaging ability, training aids, desire for business and warranties and claim policies were no longer relevant to the current supplier selection context. In this current study, articles published between 2001 and 2010 were reviewed to evaluate the relevance of previous findings with current market requirements. A broad search was carried out by focusing on refereed publications in the fields of engineering, production, marketing and finance, as SCM is related to these major disciplines. Table 5 provides a number of articles in which each criterion was addressed and a comparison of the factors considered between the research findings of Cheraghi et al. and the current study. Table 6 in the Appendix categorises all articles (from 2001-2010) based on the 36 criteria identified numerically in Table 5. However, the interested reader is referred to Cheraghi et al. (2004) and Weber et al. (1991) for relevant details of the criteria used from 1966-2001. From this Table, it is recognised that price, quality and delivery are still the dominant factors when considering any suppliers. Initially, Dickson only considered net pricing; however, the total cost of ownership (TCO) is used today to quantify all the related costs of a purchased item throughout its life cycle. Suppliers are expected to be able to meet quality specifications and a specified delivery schedule at a reasonable price for offered products or services. Having a notable fitness in production facilities and capacity gives the purchaser the confidence in considering the supplier's offer. A prospective supplier should have an ideal ratio between average manufacturing capacity and the average purchaser's consumption per unit of time. In addition to the 
aforementioned criteria, technical capability has a significant impact on the evaluation process as the buying organisation is concerned with the supplier's current and future technological capability.

Table 5. Comparison of selection attributes (1966-2001 and 2001-2010)

\begin{tabular}{|c|c|c|c|c|}
\hline & Criterion & $\begin{array}{l}\text { Frequency (1966- } \\
\text { 2001) }\end{array}$ & $\begin{array}{l}\text { Frequency } \\
(2001-2010) \\
\end{array}$ & Overall \\
\hline 1 & Quality $^{*}$ & 71 & 37 & 108 \\
\hline 2 & Delivery $^{*}$ & 75 & 36 & 111 \\
\hline 3 & Performance history ${ }^{*}$ & 11 & 10 & 21 \\
\hline 4 & Warranties and claim policies ${ }^{*}$ & 1 & 5 & 6 \\
\hline 5 & $\begin{array}{l}\text { Production facilities and } \\
\text { capacity }^{*}\end{array}$ & 35 & 20 & 55 \\
\hline 6 & Price ${ }^{*}$ & 81 & 37 & 118 \\
\hline 7 & Technical capability $^{*}$ & 30 & 24 & 54 \\
\hline 8 & Financial position $^{*}$ & 15 & 17 & 32 \\
\hline 9 & Procedural compliance ${ }^{*}$ & 4 & 0 & 4 \\
\hline 10 & Communication system $^{*}$ & 7 & 7 & 14 \\
\hline 11 & $\begin{array}{l}\text { Reputation and position in } \\
\text { industry }^{*}\end{array}$ & 10 & 8 & 18 \\
\hline 12 & Desire for business ${ }^{*}$ & 2 & 2 & 4 \\
\hline 13 & Management and organisation ${ }^{*}$ & 17 & 22 & 39 \\
\hline 14 & Operating controls ${ }^{*}$ & 5 & 0 & 5 \\
\hline 15 & Repair service* & 18 & 11 & 29 \\
\hline 16 & Attitude* & 14 & 6 & 20 \\
\hline 17 & Impression $^{*}$ & 6 & 4 & 10 \\
\hline 18 & Packaging ability $^{*}$ & 5 & 4 & 9 \\
\hline 19 & Labour relations record* & 4 & 6 & 10 \\
\hline 20 & Geographical location* & 17 & 12 & 29 \\
\hline 21 & Amount of past business ${ }^{*}$ & 1 & 2 & 3 \\
\hline 22 & Training aids ${ }^{*}$ & 3 & 0 & 3 \\
\hline 23 & Reciprocal arrangements ${ }^{*}$ & 5 & 0 & 5 \\
\hline 24 & Reliability & NA & 11 & 11 \\
\hline 25 & Flexibility & NA & 19 & 19 \\
\hline 26 & Process improvement & NA & 12 & 12 \\
\hline 27 & Product development & NA & 19 & 19 \\
\hline 28 & $\begin{array}{l}\text { Environmental and social } \\
\text { responsibility }\end{array}$ & NA & 9 & 9 \\
\hline 29 & Occupational safety and health & NA & 4 & 4 \\
\hline 30 & Integrity & NA & 5 & 5 \\
\hline 31 & Professionalism & NA & 4 & 4 \\
\hline 32 & JIT & NA & 5 & 5 \\
\hline 33 & Commitment & NA & 9 & 9 \\
\hline 34 & Economy situation & NA & 1 & 1 \\
\hline 35 & Long-term relationship & NA & 4 & 4 \\
\hline 36 & Political situation & NA & 2 & 2 \\
\hline
\end{tabular}

* Criteria outlined by Dickson (1966). 
Management and organisation of the supplier's firm is also evaluated as the company's strategy, organisational structure and management attitude gives the buyer an assurance of its survivability and sustainability. In fostering a successful buyersupplier relationship, the sound financial position of the supplier convinces the buyer of the viability of the supplier throughout the intended period of supply. The repair service attribute is given importance as it depicts the ability of a supplier in problem-solving and its customer service level. Geographical location is also a preferred criterion as it will determine whether to engage a local or distant supplier; this becomes more influential when dealing with international suppliers as issues of trade barriers and imposed tariffs might arise. Suppliers are also evaluated based on their past performance which could be used as a baseline to avoid any non-performers being awarded any future contracts. Although attitude is a subjective element, it is widely accepted as a criterion to eliminate any suppliers with negative characteristics.

Evolving criteria have emerged due to the competitive market as the number of suppliers has increased over the years. Therefore, the inception of new criteria is essential to narrow and qualify not only deserving but exceptional suppliers. Under the current rapid SCM transformation edge, the reliability and flexibility of each supplier are considered as the key contributing factors. Flexibility can be deemed as the provision of value-added service to boost business ties with the customer. The purchaser expects the supplier to be reliable in delivering the required quantity of products to the right destination, at the agreed upon time and in contractually acceptable conditions. Emphasis is also given to the supplier's commitment towards continuous product development and improvement. Suppliers with continuous process improvement initiatives such as total quality management (TQM), Six Sigma and ISO 9000 are regarded as able to further enhance the standard of business operations. In order to minimise the negative environmental impact of delivered products or rendered services, the supplier's ability to manage environmental factors is considered in the selection process. In addition to that, the supplier's commitment towards social responsibility such as donations to charities gives a good impression to the decision maker.

Occupational health and safety practice by suppliers is essential in order to avoid any industrial accidents incurred during the process of delivering and installing products by the supplier's personnel. Other convincing factors in awarding the contract are integrity, professionalism and commitment, as well as economic and political situations.

\section{SUPPLIER SELECTION METHODS}

There are a large number of decision making methods which have been developed to assist in the supplier selection process. By catering to the changing needs of supplier selection criteria, selection methods are improvised from time to time. Some methods have been popular for years, while other methods have been introduced recently. Due to the multiple criteria of supplier selection, a decision making tool accommodating both quantitative and qualitative criteria is preferred.

Traditionally used methods are considered as appraisal methods by reviewing objective and subjective evaluation criteria (Humphreys et al., 1998). Categorical and weighted point methods are popular due to their simplicity and quicker evaluation process. However, the cost-ratio method has been seen as a complex model and requires a comprehensive cost-accounting system to generate precise cost data (Willis and Huston, 1989). Vendor profile analysis is a modified version of the weighted point method employing Monte Carlo simulation to replace ratings based on intuitive 
judgment (Thompson, 1990). Dimensional analysis was proposed by Willies et al. (1993) which allows for combining several criteria of different dimensions and varying importance into a single dimensionless entity. Based on Saaty (1980), several researchers (Nydick and Hill, 1992; Partovi et al., 1989; Narasimhan, 1983) have suggested the use of the analytic hierarchy process (AHP) due to its inbuilt ability to handle both qualitative and quantitative criteria. Departing from this method, multiple attribute utility theory (MAUT) was introduced to handle multiple conflicting criteria existing in international supplier selection (Stewart and Mohamed, 2002; Zionts, 1992). Another modified approach is the implementation of the total cost of ownership (TCO), which quantifies all costs involved throughout the purchased item's lifecycle (De Boer et al., 2001).

The mathematical programming method is a way of optimising the selection of several suppliers in order to maximise an objective function based on the constraints faced by suppliers and buyers. The linear programming technique has been used to decide on the best supplier according to controlling criteria defined by the purchaser (Moore and Fearson, 1973). The goal programming method was developed to perform supplier selection based on the goals required by the client, such as cost, quality and delivery (Karpak et al., 2001). Data envelopment analysis (DEA) is used to classify suppliers according to their efficiency levels (Braglia and Petroni, 2000). Artificial intelligence (AI) is based on computer-aided systems which rely on historical data for decision making. Popular AI systems in use for supplier selection purposes are neural networks (NN) and case-based reasoning (CBR) (Humphreys et al., 2003a; Albino and Garavelli, 1998; Cook, 1997). More recently, swarm intelligence methods, namely ant colony and particle optimisation, have been introduced to cater to multi-objective problems (Gholamian and Ghomi, 2006). The application of the ant colony model in the supplier selection process enables solving many combinatorial optimisation problems within a reasonable time (Tsai et al., 2010). Particle swarm optimisation (PSO), based a fuzzy neural network, has been used to derive rules for qualitative data in achieving a more precise supplier selection decision (Chakraborty et al., 2011). In recent development, the DNA-based hybrid genetic algorithm has been favoured for solving non-linear constrained optimisation problems (Chen and Wang, 2010). On the other hand, statistical methods are also used in selecting suppliers, especially when dealing with stochastic uncertainty (Ronen and Trietsch, 1988; Hinkle et al., 1969). Although both statistical and neural network methods have the same aim of assisting decision making, some distinct differences exist between them such as: (1) terminology; (2) philosophy; (3) goals; (4) model development; and (5) knowledge acquisition (Karlaftis and Vlahogianni, 2010). Most terms used in NN modelling are different compared to those used in statistics, which sometimes leads to confusion among researchers. The underlying philosophy of NN emphasises implementation, while statistics are geared more towards inference and estimation. Opposite to the aim of statistics of providing a predictive model, NN aims to provide an efficient representation of the underlying data. The most significant difference between both approaches in the model development stage is the learning process. This characteristic constitutes the flexibility, inference mechanism and time acquired for model development. Comparatively, the knowledge acquisition process for $\mathrm{NN}$ is more simplified than the statistical model. In the literature, it can be seen that hardly any evidence shows that the electricity supply industry embraces systematic supplier selection techniques. However, any suitable supplier selection method to be employed by the purchaser depends on the required capability and their affordability in investing in such a facility. 


\section{CONCLUSIONS}

In the current competitive business environment, the relationship between buyers and suppliers is no longer as antagonistic as the traditional way, but emphasis is geared more towards forging partnerships which benefit both parties. The emergence of the supply chain concept made buyers and suppliers realise that long-term cooperation could be jeopardised by a lack of mutual trust. High priority is given towards suppliers who are able to deliver promises and commit to and support the buyer's vision. Supplier selection has become an important focus for every purchasing organisation as it dictates the buyer's operational and financial positions. This review of the literature provides a basis for the identification and definition of supplier selection metrics in the Malaysian electricity supply industry. There is a need to investigate the supplier selection practices in this industry as it is a unique sector by itself. Not all criteria and decision methods used by the manufacturing industry might be applicable to the electricity supply industry. The traditional set of supplier selection criteria comprising price, delivery, quality and service is considered universal for most industries. However, it is imperative to understand that buyers, suppliers and end-users might have different definitions for each metric when there are no standard supplier selection metrics and definitions for a particular industry. Positive interactions between the buyer and the supplier in creating long-term relationships are also subject to evolving supplier selection criteria. As the pace of market globalisation quickens, buyers expect suppliers to excel in nontraditional attributes such as reliability, flexibility, environmental responsibility, process improvement and other current customer-defined criteria. Therefore, having a good set of supplier selection metrics and corresponding definitions is of critical significance for the organisational success of SCM. From the standpoint of the decision support model, the supplier selection problem is multi-attribute in nature, and requires suppliers to be scored based on a weighting scheme for each attribute. It is the intention of this research to provide at least one of the numerous tools that will be required in order to deliver efficiency, reliability and cost effectiveness in the development of electricity supply industry infrastructure. A decision support model based on the relationship of a set of inputs (supplier performance criteria) and outputs (score of suppliers) will be developed to predict the score of suppliers for future input data specifically for the Malaysian electricity supply industry. From this review, it is suggested that the use of an artificial neural network will be an advantageous approach for supplier selection in the electrical supply industry. This is attributed to its characteristic of simulating the human brain by collecting and processing data for the purpose of remembering or learning. However, an extended study should be conducted to ascertain the applicability of this finding in the Malaysian context.

\section{ACKNOWLEDGEMENTS}

The authors would like to thank Universiti Tenaga Nasional (UNITEN) Staff Development Scheme and Auckland University of Technology (AUT) for their support. 


\section{REFERENCES}

Albino, V. and Garavelli, A.C. 1998. A neural network application to subcontractor rating in construction firms. International Journal of Project Management, 16(1): 9-14.

Altinoz, C., Kilduff, P. and Winchester Jr., S.C. 2010. Current issues and methods in supplier selection. Journal of the Textile Institute, 92(2): 128-141.

Bai, C. and Sarkis, J. 2010. Green supplier development: Analytical evaluation using rough set theory. Journal of Cleaner Production, 18(12) 1200-1210.

Bevilacqua, M. and Petroni, A. 2002. From traditional purchasing to supplier management: A fuzzy logic-based approach to supplier selection. International Journal of Logistics: Research and Applications, 5(3): 235-255.

Braglia, M. and Petroni, A. 2000. A quality assurance-oriented methodology for handling trade-offs in supplier selection. International Journal of Physical Distribution \& Logistics Management, 30(2): 96-111.

Caniels, M.C.J. and Gelderman, C.J. 2005. Purchasing strategies in the Kraljic matrix A power and dependence perspective. Journal of Purchasing and Supply Management,11(2-3): 141-155.

Chakraborty, T., Ghosh, T. and Dan, P.K. 2011. Application of analytic hierarchy process and heuristic algorithm in solving vendor selection problem. Business Intelligence Journal, 4(1): 167-177.

Chen, X. and Wang, N. 2010. Optimization of short-time gasoline blending scheduling problem with a DNA based hybrid genetic algorithm. Chemical Engineering and Processing: Process Intensification, 49(10): 1076-1083.

Cheraghi, S.H., Dadashzadeh, M. and Subramaniam, M. 2004. Critical success factors for supplier selection: An update. Journal of Applied Business Research, 20(2): 91-108.

Cook, R.L. 1997. Case-based reasoning systems in purchasing: applications and development. International Journal of Purchasing and Materials Management, 33(1): 32-39.

De Boer, L., Labro, E. and Morlacchi, P. 2001. A review of methods supporting supplier selection. European Journal of Purchasing and Supply Management, 7(2): 75-89.

Dickson, G.W. 1966. An analysis of vendor selection systems and decisions. Journal of Supply Chain Management, 2(1): 5-17.

Dubois, A. and Pedersen, A.C. 2001. Why partners do not fit into purchasing portfolio models. 17th Annual IMP Conference. Oslo, Norway.

Ellram, L.M. 1990. The supplier selection decision in strategic partnerships. Journal of Purchasing and Material Management. 26(4): 8-14.

Faris, C.W., Robinson, P.J. and Wind, Y. 1967. Industrial Buying and Creative Marketing. Boston: Allyn \& Bacon.

Florez-Lopez, R. 2007. Strategic supplier selection in the added-value perspective: A CI approach. Information Sciences, 177(5): 1169-1179.

Gholamian, M.R. and Ghomi, S.M.T.F. 2006. A hybrid computational intelligent system for multiobjective supplier selection problem. International Journal Management and Decision Making, 7(2/3): 216-233.

Hinkle, C.L., Robinson, P.J. and Green, P.E. 1969. Vendor evaluation using clusters analysis. Journal of Purchasing and Material Management, 5(3): 49-58. 
Humphreys, P., Mak, K.L. and McIvor, R. 1998. Procurement. Logistics Information Management, 11(1): 28-37.

Humphreys, P., McIvor, R. and Chan, F. 2003a. Using case-based reasoning to evaluate supplier environmental management performance. Expert Systems with Applications, 25(2): 141-153.

Humphreys, P., Shiu, W.K. and Lo, V.H.Y. 2003b. Buyer-supplier relationship: Perspectives between Hong Kong and the United Kingdom. Journal of Materials Processing Technology, 138(1-3): 236-242.

Karlaftis, M.G. and Vlahogianni, E.I. 2010. Statistical methods versus neural networks in transportation research: Differences, similarities and some insights. Transportation Research Part C: Emerging Technologies. 19(3): 387-399.

Karpak, B., Kumcu, E. and Kasuganti, R.R. 2001. Purchasing materials in the supply chain: Managing a multi-objective task. European Journal of Purchasing and Supply Management, 7(3): 209-216.

Kraljic, P. 1983. Purchasing must become supply management. Harvard Business Review, 61(5): 109-117.

Lambert, D.M., Adams, J.R. and Emmelhainz, M.A. 1997. Supplier selection in the healthcare industry: A comparison of importance and performance International Journal of Purchasing and Materials Management, 33: 16-23.

Lasch, R. and Janker, C.G. 2005. Supplier selection and controlling using multivariate analysis. International Journal of Physical Distribution \& Logistics Management, 35(6): 409-425.

Markowitz, H. 1952. Portfolio selection. Journal of Finance, 7: 77-91.

Monczka, R., Trent, R. and Handfield, R. 1998. Purchasing and Supply Chain Management. Cincinnati, Ohio: South-Western College Publishing.

Moore, D.L. and Fearson, H.E. 1973. Computer-assisted in decision-making in purchasing. Journal of Purchasing and Material Management, 9(4): 5-25.

Narasimhan, R. 1983. An analytical approach to supplier selection. Journal of Purchasing and Material Management, 19(4): 27-32.

Nydick, R.L. and Hill, R.P. 1992. Using the analytic hierarchy process to structure the supplier selection procedure. Journal of Purchasing and Materials Management, 25(2): 31-36.

Olsen, R.F. and Ellram, L.M. 1997. A portfolio approach to supplier relationships. Industrial Marketing Management, 26(2): 101-113.

Partovi, F.Y., Burton, J. and Banarjee, A. 1989. Application of analytic hierarchy process in operations management. International Journal of Operations and Production Management, 10(3): 5-19.

Ronen, B. and Trietsch, D. 1988. A decision support system for purchasing management of large projects. Operations Research, 36(6): 882-890.

Saaty, T.L. 1980. Analytic Hierarchy Process. New York: McGraw-Hill.

Sarkar, A. and Mohapatra, P.K.J. 2006. Evaluation of supplier capability and performance: A method for supply base reduction. Journal of Purchasing and Supply Management, 12(3): 148-163.

Stewart, R. and Mohamed, S. 2002. IT/IS projects selection using multi-criteria utility theory. Logistics Information Management, 15(4): 254-270.

Thompson, K.N. 1990. Supplier profile analysis. Journal of Purchasing and Materials Management, 26(1): 11-18. 
Tsai, Y.L., Yang, Y.J. and Lin, C.H. 2010. A dynamic decision approach for supplier selection using ant colony system. Expert Systems with Applications. 37(12): 8313-8321.

Wadhwa, V. and Ravindran, A.R. 2007. Vendor selection in outsourcing. Computers and Operations Research, 34(12): 3725-3737.

Watt, D.J., Kayis, B. and Willey, K. 2010. The relative importance of tender evaluation and contractor selection criteria. International Journal of Project Management, 28(1): 51-60.

Weber, C.A., Current, J.R. and Benton, W.C. 1991. Vendor selection criteria and methods. European Journal of Operational Research, 50(1): 2-18.

Willis, T.H. and Huston, C.R. 1989. Vendor requirements and evaluation in a just-intime environment. International Journal of Operations and Product Management, 10(4): 41-50.

Willis, T.H., Huston, C.R. and Pohlkamp, F. 1993. Evaluation measures of just-in-time supplier performance. Production and Inventory Management Journal, 34(2): 15.

Wisner, J.D., Leong, G.K. and Tan, K.C. 2005. Principles of supply chain management: A balanced approach. USA: South-Western, Thompson.

Xia, W. and Wu, Z. 2007. Supplier selection with multiple criteria in volume discount environments. Omega The International Journal of Management Science, 35(5): 494-504.

Ying, F. 2000. Strategic outsourcing: Evidence from British companies. Marketing Intelligence \& Planning, 18(4): 213-219.

Zionts, S. 1992. Some thoughts on research in multiple criteria decision making. Computers and Operations Research, 19(7): 567-570. 


\section{APPENDIX}

Table 6. Breakdown of supplier selection attributes considered from 2001-2010

\begin{tabular}{|c|c|c|}
\hline Criteria & $\begin{array}{l}\text { No. of } \\
\text { articles }\end{array}$ & Authors \\
\hline Quality & 37 & $\begin{array}{l}\text { Krause et al. (2001); Lee et al. (2001); Narasimhan et al. } \\
\text { (2001); Bhutta and Huq (2002); Kannan and Tan (2002); } \\
\text { Simpson et al. (2002); Bharadwaj (2003); Chan (2003); } \\
\text { Choy and Lee (2003); Humphreys et al. (2003a); } \\
\text { Shahadat (2003); Chan and Chan (2004); Hong et al. } \\
\text { (2005); Kumar et al. (2005); Lasch and Janker (2005); } \\
\text { Ndubisi et al. (2005); Pi and Low (2005); Teng and } \\
\text { Jaramillo (2005); Hsu et al. (2006); Kannan and Tan } \\
\text { (2006); Sarkar and Mohapatra (2006); El-Sawalhi et al. } \\
\text { (2007); Florez-Lopez (2007); Ho et al. (2007); Wadhwa } \\
\text { and Ravindran (2007); Xia and Wu (2007); Tahriri et al. } \\
\text { (2008); Vahdani et al. (2008); Aretoulis et al. (2009); } \\
\text { Inemek and Tuna (2009); Kasirian and Yusuff (2009); } \\
\text { Kumar et al. (2009); Ordoobadi (2009); Thanaraksakul } \\
\text { and Phruksaphanrat (2009); Ho et al. (2010); Kang and } \\
\text { Lee (2010); Park et al. (2010) }\end{array}$ \\
\hline Delivery & 36 & $\begin{array}{l}\text { Krause et al. (2001); Lee et al. (2001); Narasimhan et al. } \\
\text { (2001); Kannan and Tan (2002); Simpson et al. (2002); } \\
\text { Barla (2003); Bharadwaj (2003); Choy and Lee (2003); } \\
\text { Humphreys et al. (2003a); Shahadat (2003); Chan and } \\
\text { Chan (2004); Hong et al. (2005); Kumar et al. (2005); } \\
\text { Lasch and Janker (2005); Ndubisi et al. (2005); Pi and } \\
\text { Low (2005); Teng and Jaramillo (2005); Hsu et al. } \\
\text { (2006); Kannan and Tan (2006); Sarkar and Mohapatra } \\
\text { (2006); Florez-Lopez (2007); Ho et al. (2007); Huang } \\
\text { and Keskar (2007); Wadhwa and Ravindran (2007); Xia } \\
\text { and Wu (2007); Tahriri et al. (2008); Aretoulis et al. } \\
\text { (2009); Inemek and Tuna (2009); Kasirian and Yusuff } \\
\text { (2009); Kumar et al. (2009); Ordoobadi (2009); } \\
\text { Thanaraksakul and Phruksaphanrat (2009); Ho et al. } \\
\text { (2010); Kang and Lee (2010); Park et al. (2010); Wu } \\
\text { and Weng (2010) }\end{array}$ \\
\hline $\begin{array}{l}\text { Performance } \\
\text { history }\end{array}$ & 10 & $\begin{array}{l}\text { Kannan and Tan (2002); Chan (2003); Shahadat (2003); } \\
\text { Hsu et al. (2006); El-Sawalhi et al. (2007); Tahriri et al. } \\
\text { (2008); Kasirian and Yusuff (2009); Kumar et al. } \\
\text { (2009); Thanaraksakul and Phruksaphanrat (2009); Watt } \\
\text { et al. (2010) }\end{array}$ \\
\hline $\begin{array}{l}\text { Warranties and } \\
\text { claim policies }\end{array}$ & 5 & $\begin{array}{l}\text { Simpson et al. (2002); Shahadat (2003); Xia and Wu } \\
\text { (2007); Tahriri et al. (2008); Thanaraksakul and } \\
\text { Phruksaphanrat (2009) }\end{array}$ \\
\hline
\end{tabular}




\begin{tabular}{|c|c|c|}
\hline Criteria & $\begin{array}{l}\text { No. of } \\
\text { articles }\end{array}$ & Authors \\
\hline $\begin{array}{l}\text { Production } \\
\text { facilities and } \\
\text { capacity }\end{array}$ & 20 & $\begin{array}{l}\text { Humphreys et al. (2001); Lee et al. (2001); Bhutta and } \\
\text { Huq (2002); Simpson et al. (2002); Chan (2003); Choy } \\
\text { and Lee (2003); Humphreys et al. (2003b); Hsu et al. } \\
\text { (2006); Kannan and Tan (2006); Sarkar and Mohapatra } \\
\text { (2006); El-Sawalhi et al. (2007); Ho et al. (2007); Huang } \\
\text { and Keskar (2007); Xia and Wu (2007); Tahriri et al. } \\
\text { (2008); Inemek and Tuna (2009); Kasirian and Yusuff } \\
\text { (2009); Thanaraksakul and Phruksaphanrat (2009); Ho } \\
\text { et al. (2010); Kang and Lee (2010) }\end{array}$ \\
\hline Price & 37 & $\begin{array}{l}\text { Humphreys et al. (2001); Krause et al. (2001); } \\
\text { Bevilacqua and Petroni (2002); Kannan and Tan (2002); } \\
\text { Simpson et al. (2002); Barla (2003); Bharadwaj (2003); } \\
\text { Chan (2003); Choy and Lee (2003); Humphreys et al. } \\
\text { (2003b); Shahadat (2003); Chan and Chan (2004); Hong } \\
\text { et al. (2005); Lasch and Janker (2005); Ndubisi et al. } \\
\text { (2005); Pi and Low (2005); Teng and Jaramillo (2005); } \\
\text { Hsu et al. (2006); Sarkar and Mohapatra (2006); Florez- } \\
\text { Lopez (2007); Ho et al. (2007); Huang and Keskar } \\
\text { (2007); Wadhwa and Ravindran (2007); Xia and Wu } \\
\text { (2007); Tahriri et al. (2008); Vahdani et al. (2008); } \\
\text { Aretoulis et al. (2009); Inemek and Tuna (2009); } \\
\text { Kasirian and Yusuff (2009); Kumar et al. (2009); } \\
\text { Ordoobadi (2009); Thanaraksakul and Phruksaphanrat } \\
\text { (2009); Ho et al. (2010); Kang and Lee (2010); Park et } \\
\text { al. (2010); Watt et al. (2010); Wu and Weng (2010) }\end{array}$ \\
\hline $\begin{array}{l}\text { Technical } \\
\text { capability }\end{array}$ & 24 & $\begin{array}{l}\text { Lee et al. (2001); Narasimhan et al. (2001); Bevilacqua } \\
\text { and Petroni (2002); Kannan and Tan (2002); Simpson et } \\
\text { al. (2002); Barla (2003); Chan (2003); Humphreys et al. } \\
\text { (2003b); Shahadat (2003); Ndubisi et al. (2005); Kannan } \\
\text { and Tan (2006); El-Sawalhi et al. (2007); Ho et al. } \\
\text { (2007); Xia and Wu (2007); Tahriri et al. (2008); } \\
\text { Vahdani et al. (2008); Aretoulis et al. (2009); Inemek } \\
\text { and Tuna (2009); Thanaraksakul and Phruksaphanrat } \\
\text { (2009); Ho et al. (2010); Kang and Lee (2010); Park et } \\
\text { al. (2010); Watt et al. (2010); Wu and Weng (2010) }\end{array}$ \\
\hline $\begin{array}{l}\text { Financial } \\
\text { position }\end{array}$ & 17 & $\begin{array}{l}\text { Humphreys et al. (2001); Lee et al. (2001); Bevilacqua } \\
\text { and Petroni (2002); Kannan and Tan (2002); Simpson et } \\
\text { al. (2002); Barla (2003); Chan (2003); Choy and Lee } \\
\text { (2003); Humphreys et al. (2003b); Hong et al. (2005); } \\
\text { Hsu et al. (2006); Sarkar and Mohapatra (2006); El- } \\
\text { Sawalhi et al. (2007); Inemek and Tuna (2009); } \\
\text { Thanaraksakul and Phruksaphanrat (2009); Ho et al. } \\
\text { (2010); Wu and Weng (2010) }\end{array}$ \\
\hline
\end{tabular}




\begin{tabular}{|c|c|c|}
\hline Criteria & $\begin{array}{l}\text { No. of } \\
\text { articles }\end{array}$ & Authors \\
\hline $\begin{array}{l}\text { Communication } \\
\text { system }\end{array}$ & 7 & $\begin{array}{l}\text { Humphreys et al. (2001); Kannan and Tan (2002); } \\
\text { Humphreys et al. (2003b); Shahadat (2003); Sarkar and } \\
\text { Mohapatra (2006); Ho et al. (2007); Thanaraksakul and } \\
\text { Phruksaphanrat (2009) }\end{array}$ \\
\hline $\begin{array}{l}\text { Reputation and } \\
\text { position in } \\
\text { industry }\end{array}$ & 8 & $\begin{array}{l}\text { Shahadat (2003); Hsu et al. (2006); Sarkar and } \\
\text { Mohapatra (2006); Ho et al. (2007); Kasirian and Yusuff } \\
\text { (2009); Thanaraksakul and Phruksaphanrat (2009); Ho } \\
\text { et al. (2010); Watt et al. (2010) }\end{array}$ \\
\hline $\begin{array}{l}\text { Desire for } \\
\text { business }\end{array}$ & 2 & $\begin{array}{l}\text { Shahadat (2003); Thanaraksakul and Phruksaphanrat } \\
\text { (2009) }\end{array}$ \\
\hline $\begin{array}{l}\text { Management } \\
\text { and } \\
\text { organisation }\end{array}$ & 22 & $\begin{array}{l}\text { Humphreys et al. (2001); Narasimhan et al. (2001); } \\
\text { Bevilacqua and Petroni (2002); Kannan and Tan (2002); } \\
\text { Simpson et al. (2002); Barla (2003); Chan (2003); Choy } \\
\text { and Lee (2003); Humphreys et al. (2003b); Shahadat } \\
\text { (2003); Hsu et al. (2006); Sarkar and Mohapatra (2006); } \\
\text { El-Sawalhi et al. (2007); Ho et al. (2007); Tahriri et al. } \\
\text { (2008); Aretoulis et al. (2009); Inemek and Tuna (2009); } \\
\text { Thanaraksakul and Phruksaphanrat (2009); Ho et al. } \\
\text { (2010); Park et al. (2010); Watt et al. (2010); Wu and } \\
\text { Weng (2010) }\end{array}$ \\
\hline $\begin{array}{l}\text { Operating } \\
\text { controls }\end{array}$ & Nil & - \\
\hline Repair service & 11 & $\begin{array}{l}\text { Bevilacqua and Petroni (2002); Bhutta and Huq (2002); } \\
\text { Kannan and Tan (2002); Bharadwaj (2003); Choy and } \\
\text { Lee (2003); Florez-Lopez (2007); Xia and Wu (2007); } \\
\text { Ho et al. (2007); Kasirian and Yusuff (2009); } \\
\text { Thanaraksakul and Phruksaphanrat (2009); Ho et al. } \\
\text { (2010) }\end{array}$ \\
\hline Attitude & 6 & $\begin{array}{l}\text { Shahadat (2003); Sarkar and Mohapatra (2006); Ho et } \\
\text { al. (2007); Vahdani et al. (2008); Kumar et al. (2009); } \\
\text { Thanaraksakul and Phruksaphanrat (2009) }\end{array}$ \\
\hline Impression & 4 & $\begin{array}{l}\text { Hong et al. (2005); Ho et al. (2007); Thanaraksakul and } \\
\text { Phruksaphanrat (2009); Wu and Weng (2010) }\end{array}$ \\
\hline $\begin{array}{l}\text { Packaging } \\
\text { ability }\end{array}$ & 4 & $\begin{array}{l}\text { Humphreys et al. (2001); Simpson et al. (2002); } \\
\text { Humphreys et al. (2003b); Thanaraksakul and } \\
\text { Phruksaphanrat (2009) }\end{array}$ \\
\hline $\begin{array}{l}\text { Labour } \\
\text { relations record }\end{array}$ & 6 & $\begin{array}{l}\text { Humphreys et al. (2001); Simpson et al. (2002); Choy } \\
\text { and Lee (2003); Humphreys et al. (2003b); Sarkar and } \\
\text { Mohapatra (2006); Thanaraksakul and Phruksaphanrat } \\
\text { (2009) }\end{array}$ \\
\hline $\begin{array}{l}\text { Geographical } \\
\text { location }\end{array}$ & 12 & $\begin{array}{l}\text { Humphreys et al. (2001); Bevilacqua and Petroni (2002); } \\
\text { Kannan and Tan (2002); Simpson et al. (2002); Barla } \\
\text { (2003); Humphreys et al. (2003b); Hsu et al. (2006); } \\
\text { Sarkar and Mohapatra (2006); Ho et al. (2007); Kasirian } \\
\text { and Yusuff (2009); Kumar et al. (2009); Thanaraksakul } \\
\text { and Phruksaphanrat (2009) }\end{array}$ \\
\hline
\end{tabular}




\begin{tabular}{|c|c|c|}
\hline Criteria & $\begin{array}{l}\text { No. of } \\
\text { articles }\end{array}$ & Authors \\
\hline $\begin{array}{l}\text { Amount of past } \\
\text { business }\end{array}$ & 2 & $\begin{array}{lllll}\text { El-Sawalhi et al. } & \text { (2007); } & \text { Thanaraksakul and } \\
\text { Phruksaphanrat (2009) } & & & \end{array}$ \\
\hline Training aids & Nil & - \\
\hline $\begin{array}{l}\text { Reciprocal } \\
\text { arrangements }\end{array}$ & Nil & - \\
\hline Reliability & 11 & $\begin{array}{l}\text { Shahadat (2003); Teng and Jaramillo (2005); Florez- } \\
\text { Lopez (2007); Xia and Wu (2007); Aretoulis et al. } \\
\text { (2009); Inemek and Tuna (2009); Kasirian and Yusuff } \\
\text { (2009); Kumar et al. (2009); Ordoobadi (2009); } \\
\text { Thanaraksakul and Phruksaphanrat (2009) }\end{array}$ \\
\hline Flexibility & 19 & $\begin{array}{l}\text { Humphreys et al. (2001); Krause et al. (2001); } \\
\text { Narasimhan et al. (2001); Bevilacqua and Petroni } \\
\text { (2002); Kannan and Tan (2002); Humphreys et al. } \\
\text { (2003b); Shahadat (2003); Chan and Chan (2004); Teng } \\
\text { and Jaramillo (2005); Hsu et al. (2006); Ho et al. (2007); } \\
\text { Huang and Keskar (2007); Vahdani et al. (2008); } \\
\text { Kasirian and Yusuff (2009); Kumar et al. (2009); } \\
\text { Thanaraksakul and Phruksaphanrat (2009); Ho et al. } \\
\text { (2010); Kang and Lee (2010); Wu and Weng (2010) }\end{array}$ \\
\hline $\begin{array}{l}\text { Process } \\
\text { improvement }\end{array}$ & 12 & $\begin{array}{l}\text { Humphreys et al. (2001); Narasimhan et al. (2001); } \\
\text { Bevilacqua and Petroni (2002); Kannan and Tan (2002); } \\
\text { Simpson et al. (2002); Kumar et al. (2005); Sarkar and } \\
\text { Mohapatra (2006); Ho et al. (2007); Inemek and Tuna } \\
\text { (2009); Kumar et al. (2009); Thanaraksakul and } \\
\text { Phruksaphanrat (2009); Wu and Weng (2010) }\end{array}$ \\
\hline $\begin{array}{l}\text { Product } \\
\text { development }\end{array}$ & 19 & $\begin{array}{l}\text { Humphreys et al. (2001); Krause et al. (2001); Lee et al. } \\
\text { (2001); Narasimhan et al. (2001); Bhutta and Huq } \\
\text { (2002); Simpson et al. (2002); Kannan and Tan (2002); } \\
\text { Bharadwaj (2003); Chan (2003); Choy and Lee (2003); } \\
\text { Shahadat (2003); Chan and Chan (2004); Hsu et al. } \\
\text { (2006); Kannan and Tan (2006); Florez-Lopez (2007); } \\
\text { Ho et al. (2007); Ordoobadi (2009); Thanaraksakul and } \\
\text { Phruksaphanrat (2009); Ho et al. (2010) }\end{array}$ \\
\hline $\begin{array}{l}\text { Environmental } \\
\text { and social } \\
\text { responsibility }\end{array}$ & 9 & $\begin{array}{l}\text { Humphreys et al. (2001); Humphreys et al. (2003a); } \\
\text { Humphreys et al. (2003b); Ho et al. (2007); Huang and } \\
\text { Keskar (2007); Tahriri et al. (2008); Thanaraksakul and } \\
\text { Phruksaphanrat (2009); Bai and Sarkis (2010); Ho et al. } \\
\text { (2010) }\end{array}$ \\
\hline $\begin{array}{l}\text { Occupational } \\
\text { safety and } \\
\text { health }\end{array}$ & 4 & $\begin{array}{l}\text { El-Sawalhi et al. (2007); Huang and Keskar (2007); } \\
\text { Thanaraksakul and Phruksaphanrat (2009); Ho et al. } \\
\text { (2010) }\end{array}$ \\
\hline Integrity & 5 & $\begin{array}{l}\text { Kannan and Tan (2002); Hsu et al. (2006); Ho et al. } \\
\text { (2007); Tahriri et al. (2008); Inemek and Tuna (2009); } \\
\text { Thanaraksakul and Phruksaphanrat (2009) }\end{array}$ \\
\hline
\end{tabular}




\begin{tabular}{|c|c|c|}
\hline Criteria & $\begin{array}{c}\text { No. of } \\
\text { articles }\end{array}$ & Authors \\
\hline Professionalism & 4 & $\begin{array}{l}\text { Simpson et al. (2002); Pi and Low (2005); Kasirian and } \\
\text { Yusuff (2009); Thanaraksakul and Phruksaphanrat } \\
\text { (2009) }\end{array}$ \\
\hline JIT & 4 & $\begin{array}{l}\text { Humphreys et al. (2001); Bevilacqua and Petroni (2002); } \\
\text { Kannan and Tan (2002); Ho et al. (2007) }\end{array}$ \\
\hline Commitment & 9 & $\begin{array}{l}\text { Lee et al. (2001); Kannan and Tan (2002); Chan (2003); } \\
\text { Chan and Chan (2004); Hsu et al. (2006); Ho et al. } \\
\text { (2007); Aretoulis et al. (2009); Inemek and Tuna (2009); } \\
\text { Park et al. (2010) }\end{array}$ \\
\hline $\begin{array}{l}\text { Economic } \\
\text { situation }\end{array}$ & 1 & Thanaraksakul and Phruksaphanrat (2009) \\
\hline $\begin{array}{l}\text { Long-term } \\
\text { relationship }\end{array}$ & 5 & $\begin{array}{l}\text { Simpson et al. (2002); Kasirian and Yusuff (2009); } \\
\text { Thanaraksakul and Phruksaphanrat (2009); Ho et al. } \\
\text { (2010); Kang and Lee (2010) }\end{array}$ \\
\hline $\begin{array}{l}\text { Political } \\
\text { situation }\end{array}$ & 2 & $\begin{array}{l}\text { Inemek and Tuna (2009); Thanaraksakul and } \\
\text { Phruksaphanrat (2009) }\end{array}$ \\
\hline
\end{tabular}

